\title{
„Parcite autem obsecro Lampridio Vestro in Zabanio redivivo, Dynastae spectatissimi...”
}

Apafi Mihály temetésének gyászbeszédei és a szász Zabanius Izsák latin orációja

Apafi Mihály, Erdély utolsó valóságos fejedelme 1690. április 15-én hunyt el Fogaras várában. Testét tíz hónap múltán 1691. február 18-án temették hitvesének poraihoz Almakeréken a lutheránus templom melletti sírkápolnába. A fölötte mondott hét beszéd közül csak háromnak a szövege maradt fenn napjainkra. Nagyari József prédikációját és Pataki István magyar szónoklatát a Debreceni Református Kollégium Levéltárában fellehető Sinai-hagyaték őrizte meg kéziratos másolatban. ${ }^{1}$ Tanulmányomban részletesebben a harmadikkal, Zabanius Izsák, szebeni rektor latin orációjával foglalkozom.

A három szöveg közül, jellemző szász alapossággal, csak Zabanius mester beszédét nyomtatták ki már a temetés évében, 1691-ben. ${ }^{2}$ Az oráció a halottnak a háztól való búcsúztatása alkalmával, Fogarason hangzott el. Nemcsak fennmaradásának módjában tér el a magyar szövegektől, és különössége sem a megfogalmazás nyelvétől ered, hanem sokkal inkább az orátor indítékaitól. Zabanius Izsák jól tudta, miként a másik két szónok is, hogy a holtakról mondott szavak mindig az élőkhöz szólnak, különösen ha azok forduló egek, változó csillagzatok alatt hangzanak el. A magyar szónokok szövegéhez képest, melyek a nemzeti király eszményének megfelelö patriarchális monarchát dicsérnek és siratnak Apafi személyében, a szebeni rektor szónoklata sokféle hallgatói igényhez igazodott Erdély történelmének abban a korszakában, melyben hatalmi rendszerek váltása zajlott, és mindaz, ami később szilárd fundamentummá tömörült, ekkor még folyékony és ingatag volt.

1691-ben nem volt még egyértelmü - legalábbis a temetésen részt vevők és szereplők előtt semmiképpen sem -, hogy mi lesz az Erdély számára frissen elnyert Diploma Leopoldinum további sorsa, megvalósul-e a Diploma ígérete szerint az ifjú Apafi fejedelemsége, mekkora hatalma lesz az erdélyi ügyekben a Bánffy vezette Guberniumnak, és merre dőlnek el a szász kiváltságokat megőrző clausulák körüli tárgyalások. Tehát nem volt még ekkor egyértelmü, hogy kik és milyen mértékben lesznek nyertesei vagy vesztesei az újabb mutatio Transsylvanicának, mely most éppen az európai parthoz iga-

\footnotetext{
"Oratio Panegyrica, in solenni pompâ exequiali, Celsissimi quondam Principis ac Domini, Dn. Michaelis Apafi, Transylvanio Principis, Siculorum Comitis, \& Partium Regni Hungarioe Domini, dum Almakerekinum speliendus veheretur, à M. Isaaco ZaBAnIO, antehac SS. Theol. \& Phil. in Gymnasio Cibiniensi P. P. Gymnasiiq ${ }_{3}$ Rectore, nunc Ecclesiae Orbacensis Pastore, ad majorem Dei gloriam, \& prosperiorem suce Celsitudinis memoriam, Fogarasini instituta, Anno 1691. die 16. Febr. Cibinii Imprimebat Johannes Hermelius, 7. (A továbbiakban: Zabanıus, Oratio Panegyrica.)

${ }^{1}$ Tiszántúli Református Egyházkerületi Levéltár, I.24.a.5. [Z 38], 809-869.

${ }^{2}$ Lásd a csillaggal jelölt jegyzetet.
} 
zítja az irányt. Mindezek arra késztették a szász szónokot, hogy Nagyari József és Pataki István magyar beszédeinek múlthoz ragaszkodó egyértelműségével szemben ahhoz az elvhez igazítsa mondandóját, amelyet az ifjú Teleki Mihály Fejedelmi lélek címü politikai traktátusa interesnek nevez, ${ }^{3}$ melyet mi csak nevezzünk így egyszerüen érdeknek, sőt egy kis megszorítással szász érdeknek. ${ }^{4}$

Zabanius, azaz Czabán Izsák ugyanis 1632-ben a Bars vármegyebeli Brogyánban született. Evangélikus volt, Sopronban majd Wittenbergben tanult. 1661 és 1673 közt Eperjesen tanított, majd magyarországi bolyongásai után Erdélyben kötött ki, és Szebenben teljesen a szász ügy szolgálatába állott. 1676-tól a szebeni evangélikus kollégium teológia- és filozófiatanára lett. A szász városban hunyt el 1707-ben. Kinyomtatott beszédét - mint ő nevezi - a szász Helikon mecénásának és persze saját patrónusának, Valentinius Franck, szász királybírónak és szász grófnak, a Gubernium tanácsurának dedikálta. Franck Bálint is a régiről újra váltó erdélyi figurák egyike volt. Méltóságait még Apafitól kapta, 1686-ban lett szász királybíró, és egy év múlva a fejedelem a tanácsurak közé emelte. De Franck aláírása is szerepel az 1688-ban Caraffának kinyilvánított erdélyi hüségnyilatkozaton (Declaratio Transylvaniae in fidelitatem ...), és 1692-töl az új Gubernium tagja lett. Öt is grófi címmel tüntette ki Lipót úgy, mint a hajdani kuruc Telekit, csak ő a magyar foúrral ellentétben helikoni mecénásként óvatosabb életet élt, és ezt nem post mortem kapta meg.

A tanulmány címében idézett mondatot, mely Zabanius beszédének citátuma, akár bocsánatkérésnek is értelmezhetjük: „Mégis kérlek titeket, engedjetek meg, tekintetes uraim, a ti Zabaniusban újra éledt Lampridiusotoknak..."5 Mit kell és mi okból elnézniük a tekintetes dynastáknak, és miért Lampridiusban éledett újjá a szász rektor? Nézzük tehát Lampridiust! Ő a Historia Augusta történetíróinak egyike, és Zabanius ebben az életrajzgyüjteményben szereplő Alexander Severus-életrajz miatt érzett vele lelki rokonságot. ${ }^{6}$ Lampridius ugyanis szintén hanyatló időkben, a Krisztus utáni 3. századi Rómában élt. Az általa megörökített Alexander Severus császár is dinasztiájának utolsó tagja volt. Lampridius műve speculum regium, azaz királytükör, mely a császár idealizált

\footnotetext{
${ }^{3}$ Hargittay Emil, Katolikus fejedelmi tükör református forditásban (Ifj. Teleki Mihály: Fejedelmi lélek, 1689) = H. E., Gloria, fama, literatura: Az uralkodói eszmény a régi magyarországi fejedelmi tükrökben, Bp., Universitas, 2001, 91.

${ }^{4}$ A Fejedelmi lélek Johann Adam Weber Spiritus principalis boni principis című munkájának fordítása. Teleki interesének Weber helyes latinságú interesse infinitivusa - 'érdekében áll’ - felel meg. Weber a X. caputban pontosan meghatározza mit ért rajta: „Interesse videtur in hoc mundo Primum mobile esse. Appositè Itali Ognuno tira l'acqua al suo molino. Ogni galeotto, voga a sè." Johann Adam Weber, Spiritus principalis boni principis, Salisburgi, Mayr, 1674, 39. (Kiemelés az eredetiben.) „Az érdek a világon az első mozgató. Az olaszok ezt hasonlóképpen így mondják: Mindenki magának evez, Mindenki a maga malmára hajtja a vizet." Teleki Mihály, Fejedelmi Lelek, Kolozsvár, Némethi Mihály, 1689, X. rész, 169, (RMK I, 1373). (Kiemelés az eredetiben.)

${ }^{5}$ Zabanius, Oratio Panegyrica, 7.

${ }^{6}$ Havas László, Bevezetés a Historia Augustához = Historia Augusta, Debrecen, Multiplex Media, 2003, 24. Aelius Lampridius, Alexander Severus, ford. Soltész Márk = Uo., 292-342.
} 

SPECTATISSIMI..."

alakjában a princeps bonust, a senatussal együtt kormányzó jó uralkodót mutatja be, aki édesanyjával, Iulia Avita Mamaeával együtt bölcs és művelt tanácsadóktól körülvéve, békességben és jólétben kormányozza a birodalmat. Lampridius beállítása szerint neki is jósága, szelídsége, művelt szelleme okozta a végzetét. Noha Zabanius csak utalást tesz szónoklatában Alexanderre, mégsem nehéz ebben párhuzamot találni Nagyari Józsefnek Almakeréken elmondott prédikációjával, az abban megidézett Jósiás királlyal, hiszen mindkét alak az Apafiban megtestesített jó uralkodó ideálképe.

Apafi temetése az elhunyt fejedelmet megillető ceremónia minden elemének megtartásával zajlott, csak méreteiben nem volt mérhető Bocskai vagy I. Rákóczi György, különösen Bethlen Gábor temetési pompájához, amint ez Rhédey Pál feljegyzéseiből kitünik. ${ }^{7}$ A tiszteletadás gesztusai így is bőven megvoltak a február 16-án Fogarason megkezdett, és 19-én az almakeréki gyászkápolnában bevégzett temetés pompájában és ceremóniájában.

Solum corpus! A holtaknak ugyanis megvan az az előnyük az élőkkel szemben, hogy ők az elysiumi változatlanságban már semmivel nem törődnek, míg az élőknek a változó időben szüntelen törődniük kell velük. Apafi pusztán fejedelmi méltóságánál fogva, halála után még inkább eszménnyé emelkedve, a múltból megörzött szokásaiban, döntéseiben és egész lelkében saját magyar világot idézett fel az élők számára, és ez szüntelen összevetésre és értékelésre késztette őket jelen állapotuk felől. Zabanius orációja már az exordiumban tökéletesen megragadta ezt az érzést, és a pillanatot is, hogy az ideál és mítosz auráját lehelje hősére, hiszen lehet-e alkalmasabb körülmény erre, mint a gyász katarzisa!

Az immár gazda nélkül elárvult nagy ebédlőteremben és a minden helyiségével, bútoraival Apafit idéző fogarasi várban különös erővel hatottak a szavakat kereső szónoki hezitáció közhelyei:

Vajon az APAFIak Udvarának arculatát látjuk e mai időkben, vagy inkább ez időknek viharában? Vajon uralkodás képe ez, hiszen aki csak reátekint e házra, könnyen lehet, úgy tűnik majd néki, hogy itt nem alaposan kimunkált szónoklatra, nem dagállyal hömpölygő igékre van szükség, hanem a szavak csendjére inkább, mely hallgatásával, némaságával méri fel, és beszéli el a lélek fájdalmát? ${ }^{8}$

A legfontosabb azonban a magasztos laudáció szempontjából az, hogy mit dicsérjen alanyában a szónok, és hogy a dicsérete hiteles legyen. Különösen akkor nehéz ez, ha

\footnotetext{
${ }^{7}$ Lukinich Imre, I. Apaffi [!] Mihály temetése, Századok, 1913/1, 30-33.

${ }^{8}$ Itt és a továbbiakban a szövegeket saját fordításomban közlöm. „Ea nempe Aulae APAFINAE, modernâ tempestate, intempestiâ profecto, facies est, ea Regiminis forma: ut, qui eam liminis duntaxat oculis aspexerit, facile sit animadversurus: non hic oratione opus esse lucernam redolente, non turgentibus verborum amplius, sed vocali quodam silentio quod suâ taciturnitate dolorem animi aestimet magis, atque peroret." Zabanius, Oratio Panegyrica, i. m., 2. (A nyomtatvány nem jelez sem lap, sem oldalszámokat, ezért az egyszerűség végett az oldalak sorszámát jegyzem a címlap kivételével - miként napjainkban.)
} 
azok előtt teszi, akik dicsérete tárgyát még nálánál is jobban ismerik. Nem vállalkozhatott arra, hogy a szokásos férfias fejedelmi erényeket, a vitézséget, igazságosságot magasztalja. Nem mintha a hadi témákra nem adott volna lehetőséget Apafi élete, hiszen II. Rákóczi György állandóan elrángatta szegényt esztelen háborúiba ifú hitvese mellöl. Harcolt az 1653-as moldvai hadjáratban, végigharcolta az 1655-ös lengyel háborút, és megszenvedte a tatár fogságot, legyőzte a nagyszőlősi csatában a Habsburgokkal tartó Kemény Jánost, Kara Musztafa is kimozdította őt Erdélyből a bécsi hadjáratra. Külön magyaráznom sem kell viszont, hogy ezek 1691-ben, a nem régen megkapott Diploma Leopoldinum és a temetésen díszelgő császári praesidium teremtette körülmények között miért nem lehettek a vitézség erényének bemutatására alkalmazható témák.

Az igazságosság dicsérete Bánffy Dénes fiának és a Bánffy elveszejtésében közremüködő Bethlen Miklósnak a jelenlétében szintén alkalmazhatatlan volt. Olyan erényt választott tehát Zabanius, amely minden tekintetben semleges, és ezt tette meg propositiónak egy szép Vergilius-imitatióval az első eclogából: ${ }^{9}$

Így tehát ebben a gazdag és bőséges anyagban, mely számomra a beszéd tárgyául kínálkozik, a legelső helyet foglalja el a kegyességnek és vallásosságnak az a bensőséges érzülete, mely a tiszta élet semmiben sem nyugtalankodó viselését jelenti, melyben a Felséges Fejedelem egykor úgy emelte fejét mindenki fölé, miként a ciprusok kimagaslanak a hajlékony babérbokrok fölé. ${ }^{10}$

Ez tökéletes és hiteles is volt a közismerten szemlélődő, filozófiában, teológiában igen művelt, a latin nyelvben is kiváló, a kegyességet mélyen megélő Apafi magasztalására. ${ }^{11} \mathrm{Ez}$ azonban, bármiképp forgatta Zabanius, mégsem lehet csak így magára hagyva uralkodói erény. Egy paptársának vagy humanista rektor kollégájának, vagy egy kegyes és művelt úrasszonynak megfelelő lehet, de még Franck Bálint számára is kevés, nemhogy Erdély fejedelmének. Ezért amplifikálja ennek bemutatását olyan antik históriai exemplummal, amely a militia közhelyéből, a hadi életből veszi tárgyát, és erre épít egy olyan comparatiót, amely így e passzív erény, a clementia dicséretévé válik:

\footnotetext{
${ }^{9}$ „...verum haec tantum alias inter caput extulit urbes / quantum lenta solent inter viburna cupressi.” Vergilius, Ecl, I, 24-25.

${ }^{10}$ „In tam ubere autem \& copiosâ, quae mihi se ad dicendum offerta materiâ, principem locum obtinet, intimus ille Pietatis \& Religionis sensus, nec non solicita intemerarae vitae cultura; quâ Sereniss., olim PRINCEPS, tantum alios inter caput extulit, quantum lenta solent inter viburna cupressi." ZABANIUs, Oratio Panegyrica, i. m., 3.

${ }^{11}$ Thallóczi Lajos, Az öreg Apafi könyvtára, MKsz, 1881/2-3, 121-124. - Megözvegyült édesanyjának, Petki Borbálának írta Az egesz kereztyeni vallasnak rövid Fundamentomi. Megint Kétségbenesés ellen való egynéhány lelki vigaztalások címü consolatióját (RMK I, 771.). Lefordította Mark Friedrich Wendelin Systema theologicum majus et minusát: Marcus Fridericus Wendelinusnak, a' Keresztyen Isteni Tudomanyrol irott ket könyvei (RMK I, 1161.).
} 
Tiszta életű volt Scipio, akinek afrikai győzelme dicső nevet adott: a mi fejedelmünk azonban e tisztaságnál is tisztább volt, az ő erkölcsösségére, jó hírére még maga az irigység sem hinthetett egy apró foltocskát. Igen éber volt NAGY SÁNDOR, aki az egész világ feletti hatalmat dédelgetvén a lelkében, csodálatosképpen elüzte magától az álmot, nehogy amikor a kedvező szerencse szélesebb pályát tár elé, a tunyaság, mely a siker rákfenéje és pestise, akadályozhassa őt. A Mi Fejedelmünknek sem volt örvendetes ENDYMION,${ }^{12}$ mivel amennyire mások az alvásban, amennyire mások a kockajátékban, amennyire a féktelen lakomázásban lelték kedvüket, Ö annyival inkább a szent iratok megismerésére, annyival inkább a lelkesítő erények kegyes gyakorlására áldozta idejét... ${ }^{13}$

Apafi teológiai könyveinek dicséretét is a militia közhelyéböl vett metaforával emeli meg. Így lesz a kegyes életű fejedelemből először tökéleteset alkotó művész, a híres görög festőre, Apellészre utalva, majd triumphátor, aki a tiszta kegyességet diadaljelvényként helyezi el hálaáldozatul az isteni kegyelem templomcsarnokában.

A prudentia, az okosság dicséretében idézi meg szintén erősítő párhuzamként a Historia Augusta-gyüjteményben megörökített Sextus Severust, akinek okossága abban nyilvánult meg, hogy okos tanácsadókkal vette magát körül. Zabanius a Historia Augustából merítve felsorolja ezeknek a bölcs római férfiaknak a nevét, és velük párhuzamba állítva veszi fel dicséretre Apafi tanácsadóit is a maga beszédébe, akik persze egyetlen kivételtől eltekintve az új Gubernium tagjai. Ezeknek föről före haladó magasztalását vezeti be a szerénynek tủnő engedelemkérés, melyet tanulmányom címében már idéztem:

Mégis, kérlek titeket, tekintetes urak, bocsássatok meg azért a Zabaniusban életre kelt Lampridiusotoknak, és ne illessétek a hízelgésnek azzal a vádjával, mely oly idegen az igazság megvallásától, ha a ti híretekhez [a Gubernium tagjairól van szó - M. Gy.], mely szellőről szellöre kapva az emberek füléhez szárnyal, ő [Zabanius - Lampridius - M. Gy.] a dicséret méltó babérját függeszti! ${ }^{14}$

\footnotetext{
${ }^{12}$ Egy szép ifjú vadász a görög mitológiában, aki a káriai Latmosz-hegy egyik barlangjában pihen örök álomban.

${ }^{13}$ „Castus erat Scipio, cui Africana victoria, cognomentum imposuit: sed Princeps Noster, Castitate ipsa castior, cuius verecundiae, ne livor ipse, famae sequioris maculam aspersisset. Pervigil erat ALEXANDER, qui universi orbis imperium, animo complexus, miro exemplo somnum dispellebat: ne Eidem, in pleno benignioris fortunae cursu sufflamen injiceret Socordia, victoriae pestis \& carcinoma. Nec nostrum Principem delectabat ENDYMION, qui, quantum alii somno, quantum ludis aleae, quantum intempestivis conviviis, tantum Ille sacrarum literarum cognitioni, tantum Pietati entheatumque virtutum exercitio, temporis impendebat..." Zabanius, Oratio Panegyrica, i. m., 5.

${ }^{14}$ „Parcite autem obsecro Lampridio Vestro, in Zabanio redivivo Dynastae spectatissimi, neque Ei, dicam assentationis, a confessione veritatis plane alienam, eo nomine scribite, si volitanti per auras auresve hominum famae Vestrae, debitam encomii hederam appendat." Uo., 7. - Egy kis acumen az egyébként szellemtelen szónoklatban: „volitanti per auras auresve hominum famae Vestrae”.
} 
Mintha azért kérné hallgatóinak és egyben magasztaltjainak bocsánatát, hogy őket ügyes átállókat vagy kitartó hazafiakat, ki-ki döntse el immár magában - múltjukkal, azaz Apafival együtt emlegeti az igencsak megváltozott jelenben.

A hajdani tanácsosok és egyszerre új kormánytagok egyikét a beszéd elmondásakor nem nevezte meg Zabanius. Az ő dicséretét e Pythiához illő homállyal vezeti be: „Fuere alii quoque Viri Clarissimi, quos in hac temporis angustia arcano quodam celeusmate depredicabo."15 A mondat tehát többes számú, de a következőben már szingulárisban szól a rejtélyes férfiúról, és hogy a „celeusma arcanum” később olvasói számára is érthető legyen, a nyomtatott szövegben zárójelben közli az előtte álló hallgatag névmás esetéhez illesztve: „Quid autem de eo dicam (Michaele nempe Teleki)”. ${ }^{16} \mathrm{~A}$ kérdés bizonytalanságot sugall, talán a Telekit övező gyülölet miatt, mely a hallgatóság szívébe rejtve még tovább égett. Ugyanakkor a rejtélyes hallgatás egy terjedelmes laudáció előkészítése is, mivel a leghosszabb dicsérő kunsztokat a névvel nem illetett Teleki kapta a szónoktól, többet, mint maga Apafi eddig, és különbeket is, szinte fejedelmieket és hőshöz illőket. A kimondott szavakból is pontosan rá lehet ismerni a Zernyesten halálra kaszabolt kancellárra: ${ }^{17}$

....akit a barbárok fékezhetetlen ereje ledöntött [...] Szívesen megvallom azonban, ellankad az ékesszólás minden lendülete, amidőn Öt (noha a legalkalmasabb tárgya a beszédnek) lefesti. Ô ugyanis elméjében élénk, ítéleteiben határozott, döntéseiben megfontolt, a műveltség szeretetében leginkább követésre méltó volt. ${ }^{18}$

Teleki említése ürügyén vonul be a beszédbe a korábban csak egyszer, a sas allegóriában említett Leopoldus Magnus teljes imperátori tekintélyével, és ez is nyilvánvalóvá teszi, hogy a kancellár a Habsburgok ügyét és persze a maga hatalmát promoveálta. Korábbi tetteivel azonban némelyeket súlyosan sértett a jelenlévők közül. Ö akadályozta meg Heissler tábornok segítségével Apafi halálakor, hogy annak fiát, aki jelen volt apja temetésén, és hallgatta a beszédet, a rendek fejedelmükké válasszák, és még korábban Bánffy Dénes fôvesztésének is ő volt a fö agitátora. Bánffy György, a kivégzett föúr fia fögubernátorként szintén a hallgatók közt volt. A Telekinek post mortem Lipóttól kapott gró-

\footnotetext{
${ }^{15}$ „Voltak ott más igen nevezetes férfiak is, akiket az időnek ebben a szűkösségében csak rejtett magasztalással fogok dicsérni." Uo., 8.

${ }^{16}$ „Ugyan mit mondjak róla (tudniillik Teleki Mihályról).”

${ }^{17}$ Thököly Imre 1690. augusztus 21-én a zernyesti csatában legyőzte az Erdélyt uraló Heissler tábornok és a vele tartó Teleki Mihály kancellár császári és erdélyi hadait. A csatában Heissler fogságba esett, Telekit lekaszabolták.

${ }^{18}$ „...quem infraenata barbarorum rabies e medio sustulit [...] Fateor autem lubens fatiscere impetum omnem eloquii quando in Eum (amplissimum quippe dicendi argumentum impingit. Erat enim Is ingenio sagax, judicio acer, consilio maturus, eruditionis amore quam commendatissimus." Zabanius, Oratio Panegyrica, i. m., 8.
} 

SPECTATISSIMI..."

fi címére a beszéd, hogy ne sértse érintett közönségét, nagyon finoman utal, és a halott kancellár, immár gróf korábbi machinációinak említését is kerüli, noha a jelenlévők akár segítve, akár elszenvedve Telekit, mindent tudtak róla, és mindent értettek felőle.

De lehet, hogy a névtelenség, a névtelenül megnevezés csak a tensiót segítő, tehát figyelemkeltő szónoki fogás, de mindenképpen jellemző a helyzetre, a szónokra és a hallgatókra. A figyelem ébrentartására szükség is volt, mivel a legkényesebb téma következett, a fejedelem közönye, és ennek veszélyei az államra nézve. Ezt a legismertebb államallegória, a méhek és vezérük kapcsolatának díszes leírásával készítette elö:

Egy sincs ezek közül, amelyik nem követné vezérét, mikor zengő hangjával, mint egy kürt biztatásával új gyarmatok felé akarja vezetni őket [...] Ez ugyanis az államról való gondoskodást jelenti, nehogy az valami kárt szenvedjen a Fejedelem közönye miatt. ${ }^{19}$

Apafi közönyét, azaz melankóliáját úgy magyarázta, hogy a fejedelem - jellemző metaforája ez is a beszédnek - már korábban kioltani kívánta „az érzékeny idegekbe belesütött tüzes vasat, melyet Szapolyai veszélyes ambíciója és hatalomvágya hozott Erdélyre”, ${ }^{20}$ tehát korábban kívánt elszakadni a töröktől, mint ahogy „a legyőzhetetlen LEOPOLDUS diadalmas fegyverei a barbárt Scytiába elüzték volna”. ${ }^{21}$

Apafi bánatának oka ezek szerint az volt, hogy e törekvését alattvalóinak hitszegése sikertelenné tette. Azok ugyanis Apafi számára is veszélyes helyzetet teremtve - a szónok szerint - eljátszották Lipótnak a fejedelem személye iránti bizalmát:

Nagy súllyal telepedett a Keresztyén fejedelemre ez a gondolat, hogy hiába emel jogosan panaszt alattvalóinak hitszegése miatt, miközben ő a Birodalom legfelső Méltóságára csodálatos tisztelettel tekint fel, és nem várhat majd semmiféle biztonságot, csak akkor, ha a birodalom szent diadémjával megkoronázott LEOPOLDUS ölében a legnagyobb nyugalomra találhat. ${ }^{22}$

Ezután továbbfolytatta Zabanius mester a holt fejedelem dicséretét a már kivágott mederben: iskolák támogatója, aki a hontalanul bolygó gyulafehérvári kollégiumnak atyai

\footnotetext{
19 „Nulla est, quae tinnitu sui Ducis novam educturi coloniam, ceu buccinae clangore excitata, evolantem non sequatur [...] Hoc nempe Reipublicae ita providere, ne incuria Principis, detrimenti aliquid accipiat." Uo., 9.

${ }^{20}, \ldots$ extincturus inustum teneriori sensui cauterium, quod ambitio Zapolii ac perniciosa regnandi cupido Transilvaniae induxerat." Uo.

${ }^{21}$ „... victricia invicti LEOPOLDI arma in Scythicam barbariem effidisset...” Uo.

22 „Adeo profunde Christiano Principi insederat ista opinio, ut existimarit, non posse Eum jure de suorum subditorum perfidia conqueri, qui supremam Imperii Majestatem venerabundus non suspicit, nec aliquam ab iis expectaturum securitatem, nisi in Ejusdem sinu, coronatus sacro Imperii diademate LEOPOLDUS, tutissime conquiescat." $U$.
} 
gondoskodással új hazát adott. Aztán a lamentációra, a holt elsiratására tér a beszéd ismét egy tragikus és óvatlan fordulattal:

Ha ugyanis valaki megfontoltan az ítélkezés mérlegére helyezi a Mi néhai Felséges Fejedelmünk kivételes kedvességét és az ő tőlünk való siralmas eltávozását, kétségtelenül őszinte szívvel óhajtaná, hogy az ő felépülésével a késő utódokig gyarapodni fog családjának boldog állapota. Azonban nem változik a végzet a halandók könyörgéseire, és a jelenvaló élet unott közösségébe sem helyezi vissza azt, akit már az égiek boldog társaságába sorolt. ${ }^{23}$

A reménykeltő vigasztalás - a beszéd szerint - e sötét és végzetes állapotból az, hogy a közboldogság nem kerül a jövőben sem veszélybe, mivel az ország immár az ifjú Lipót oltalmába került, aki a Birodalom Reménye, Magyarország Phoebusa etc. Tehát a szónok proszkünézisz minden arcátlanságával és gátlástalan hízelgésével dicséri fel hoszszasan a továbbiakban Apafi teteménél Lipótot, és elhalmozza mindazokkal az erényekkel, amelyeket Apafinál elhagyott. Lipót a tökéletes fejedelem példaképe, akit a kegyesség nemzett, akit a bölcsesség oktatott, a nagylelküség gyarapított, akiben versengve vetélkedik a szerencse az erénnyel.

A befejezésben mégis szót ejt Apafiról, és egy költői aposztroféval, melybe azért még újra belehinti az új uralkodónak és fiának, a magyar trónörökös I. Józsefnek a dicséretét, tehát Erdély utolsó valóságos fejedelmét e poétikus lendületű megszólítással búcsúztatja el az élők közül:

Téged is, felséges Apafi Mihály Fejedelem, Nekem legkegyelmesebb Uram, mondom Téged is e két Nap [Lipót és József - M. Gy.] világít meg Kegyességük legragyogóbb sugaraival, és szétszórja majd a szomorú léleknek ama széles árnyait, melyet a jelenvaló gyász okozott, hogy a Te ragyogó tehetséged ajándékai, melyeket ősi véreddel együtt már korábban magadévá tettél, ezekkel a hamvakkal ki ne hunyjanak, hanem végül az áhított boldogság fényességébe szerteáradjanak. ${ }^{24}$

Mire való e nagy hízelgés? Ha tekintetbe vesszük azt, hogy Zabanius szász volt, és valószínűleg a patrónusa Frank Bálint ajánlotta a gyászbúcsúztatásra, aki Lipóttól valósá-

\footnotetext{
${ }^{23}$ "Si enim quis accuratiore judicii lance \& exquisitam Sereniss. quondam Principis Nostri dexteritatem \& luctuosum Ejusdem a Nobis discessum, expenderit: intimo, haud dubie, sensu, desiderabit, ut Illius restitutione, Patria felicitas, ad seram usque posteritatem sobolescat. Sed non moventur fata, mortalium votis, nec taediosae praesentis vitae societati restituunt, quem beato coelitum consortio interuerunt." Uo. ${ }^{24}$ „Et Te Sereniss. Princeps Michael Apafi, Domine Domine Mihi gratiosissime, \& Te, inquam, Soles duo fulgentissimis Clementiae suae radiis, illustrant, crassas illas tristioris animi, tenebras, quas e praesenti luctu contraxisti, penitus dissipaturi: ne scintillantis ingenii Tui dotes, quas cum sangvine paterno jampridem imbibisti, sub istis veluti cineribus extingvantur, sed tandem aliquando in lucem se diffundant, exoptatae prosperitatis." Uo., 12-13.
} 
gos grófi címet és nemességet kapott, mindez érthető. Érthető ez abban a tekintetben is, hogy a Diploma Leopoldinum szász clausulái még megtárgyalásra vártak. Mondhatnánk tehát némi malíciával, hogy Zabanius a beszédében a szász universitas érdekei szerint lavírozott a jelenlévő ellentétes ambíciók meglehetősen érdes értési felületén. Tekintetbe kell venni azonban azt a történelmi tényt, hogy a török ölelte Erdélyben a rezsimváltási kísérleteket irgalmatlan és véres leszámolások kísérték mindkét oldalról. Zabanius hódoló szónoki gesztusai azonban arra mutatnak, hogy a fejedelemség vezetöi elfogadták a dolgok állását, és a békés kompromisszumot keresték egymással és az új hatalommal.

\section{Gyula Mikó}

Sermons Written for the Funeral of Mihály Apafi, Focusing on the Latin Oration of the Saxon Izsák Zabanius

Izsák Zabanius, rector (school teacher) of Szeben (Hermannstadt) told his Latin sermon on the funeral of Mihály Apafi, Duke of Transylvania. During his reign, Apafi succeeded in expelling the Hapsburgs and the Turkish from the territory of Hungary and Transylvania, so after the death of the duke, Transylvania was soon under the rule of Emperor Leopold I. This paper presents the way the leaders of Transylvania and especially the Saxons regulated by the new interests of the Western ruler, and how they immediately turned from a tradition of one and a half century. 